\title{
Godsbeelde in die konteks van die rouproses
}

\author{
Willem J Smith (Benoni) ${ }^{1}$ \\ Navorsingsassosiaat: Departement Praktiese Teologie \\ Universiteit van Pretoria
}

\begin{abstract}
Images of God in the context of loss grieving

Human beings express their experiences of God by means of language and images. Language not only represents or reflects experience, but also shapes it. The same holds true for religious language. Believers who experience loss, seek to find God and the role of God in their changed circumstances. During their experience of loss and grief, people can either image God in a negative or a positive way. This article investigates different imagery of God, such as the king-judge image, the family image, the friend image and the lover image. These images are explored in order to indicate their possible contribution towards nurturing hope within the context of loss grieving. The article does not express a preference for any one image of God, but rather emphasizes the importance of utilizing God images in such a way that God's presence can be experienced as moments filled with hope. The article concludes that this is achieved when the God images which people hold on to in their time of need and suffering reflect God's love and presence as mirrored by the cross and resurrection of Jesus.
\end{abstract}

\section{1. 'N INTREEWOORD}

"Mense het nog altyd hulle ervaring van God in menslike beelde en menslike taal beskryf. Dit kan nie anders nie. Menslike woorde en beelde is al wat beskikbaar is" (Dreyer 1998:549). Mense bring hulle ervaring van God tot uitdrukking in menslike beelde en menslike taal. Die ervaring van God tydens verlies, is geen uitsondering nie. "Het verschijnsel van de dood [zoals elk ander verlies] ... roept

\footnotetext{
${ }^{1} \mathrm{Dr}$ Willem J Smith (MA, PhD) is as navorsingsassosiaat betrokke by prof dr Yolanda Dreyer se navorsingsprojek "Teorieë van die Praktiese Teologie en Filosofiese Hermeneutiek", Departement Praktiese Teologie, Fakulteit Teologie, Universiteit van Pretoria. Die artikel is 'n verwerking van 'n deel van die skrywer se PhD-proefskrif, "'n Prakties-teologiese perspektief op hoop as pastorale bemagtiging en verryking in die rouproses", Universiteit van Pretoria (2003).
} 
als vanzelf de vraag op wat God met dit alles te maken heeft" (Hallewas 1989:123).

Die doel van die artikel is om aan te dui dat mense se Godsbeelde 'n positiewe of negatiewe uitwerking op hulle ervaring van God kan hê. Die volgende Godsbeelde sal in die artikel aan die orde kom:

- Monargies-juridiese beelde

- $\quad$ Familiebeelde

- Vriendskapsbeelde

- $\quad$ Beeld van God as Geliefde.

Hierdie beelde is uiteraard nie die enigste moontlike beelde van God nie. Die beelde word ondersoek as voorbeeld van hoe die wyse waarop mense God tydens 'n situasie van verlies en lyding ver-beeld, kan bydra tot die ontdekking van hoop. Moontlike ander beelde wat die liefde van God in die hoopryke menswording van Jesus Christus, kan voortdurend ontgin word. Ter wille van die bestek van hierdie artikel, sal daar egter op bogenoemde seleksie gefokus word. Myns insiens verleen sekere beelde hulle nie beter as ander tot pastorale omstandighede nie. Die ryk verskeidenheid moontlike Godsbeelde behoort net vereng te word tot net 'n paar nie. Die pastor en die pastorant het die vryheid om alle bruikbare beelde saam te ontgin en in interaksie met mekaar te laat tree tot die uiteindelike beswil van die pastorant. Godsbeelde, soos onder andere verbeeld in die Jesus-gebeure, verteenwoordig 'n rykdom waarin God se weldade aan mense in nood bekend gemaak kan word. Hierdie rykdom is tot die beskikking van die pastor en pastorant.

Negatiewe ervarings en verbeelding van God kan bydrae tot hooploosheid by mense in nood en mense wat rou. Die beelde wat mense van God het, beïnvloed hulle ervaring van God en die wyse waarop hulle hulle eie identiteit in verhouding met God belewe. Omdat gelowiges God ervaar as teenwoordig by mense, sal hulle hierdie ervaring uitdruk deur ver-beeld-end oor God te praat. Vir gelowiges is die Bybel die getuienisse van onvolmaakte mense wat God binne 'n dimensie van tyd, ruimte en spesifieke omstandighede ervaar het. Aangesien die konteks van die Bybelskrywers van dié van die lesers verskil, sal die interpretasie en verstaan van die beelde oor God verskil. Sommige beelde mag vanweë 'n andersoortige konteks opgehef word. Ander kan selfs potensieel skadelik wees vir hedendaagse mense. God se naam of wese kan nie in beelde vasgevang 
word nie. God bly altyd meer en groter as die beelde wat mense gebruik om God te beskryf. Die konteks waarbinne die pastorant soek na hoop midde-in verlies, sal die pastorant se beelde van God beïnvloed. Omgekeerd beïnvloed taal en beelde oor hoe mense hulle werklikheid ervaar. "Language not only represents or reflects experience but also shapes it. What is true for all language is also true for religious language" (Van Wijk-Bos 1995:5).

\section{MONARGIES-JURIDIESE BEELDE}

Mense soek dikwels na God se optrede of rol in 'n spesifieke gebeurtenis. Indien omstandighede beleef word as moeilik of onaangenaam, word God se rol soms gesien as dié van 'n regter wat oordeel en straf. Spore van so 'n Godsbeeld word gevind in dele van die Ou-Testamentiese wysheidsliteratuur, waar God sondaars straf vir slegte dade en regverdiges beloon vir goeie dade. 'n Klassieke voorbeeld hiervan is Job se vriende volgens wie Job se omstandighede daaraan te wyte is dat God vanweë Job se sonde die rug op hom gedraai het. Hallewas (1989:124), wat God as bron van alle dinge beskryf, meen wel dat God onder andere ook as 'n veroordelende God verstaan kan word. Hy wys egter nie daarop dat God se oordeel in Jesus Christus ook bevryding vir mense sonder hoop bring nie.

Ook in die Nuwe Testament is God regter oor die sonde (Rom 1:32; 2:116; vgl Käsemann 1980:38-39; 53-66). Wat egter die klem dra, is die verkondiging van God se genade en liefde wat anders teenwoordig by mense is en hoopvol redding aan mense in nood gee. God oordeel nie in die eerste plek nie (kyk Rom 3:21-26; 5:6-8; 2 Kor 5:19; Joh 3:16-17). In Romeine 5:6-9 sê Paulus dat Jesus Christus vir mense gesterf terwyl hulle swak, goddeloos, sondaars en vyande van God was (Rom 8:31-33). God kies steeds om by die wêreld teenwoordig te wees en daarmee versoen te wees (kyk 2 Kor 5:19). God, wat teenwoordig is in pyn en verlies, is terselfdertyd díe God wat uit genade aan mense in nood in Jesus Christus teenwoordig wil wees (kyk Sarot 1994:138).

In die Pauliniese teologie beteken die medelydende teenwoordigheid van Jesus Christus by die nood van mense dat God deur Christus die mens met God "versoen" het deur die mens te vergewe (Gal 3:13). Dit is 'n versoening (Sühnung) wat tussen God en mense plaasvind, sodat mense in hierdie versoende verhouding die teenwoordigheid van God as "naby" kan beleef. God se versoening met mense is "expiation" en nie "propitiation" nie. God se versoening met mense is nie 'n "satisfaksie", waarin 'n God wat kwaad was, deur die offer van Jesus Christus weer goed gemaak word nie. Om "ter wille van" ander iets te 
doen, dui op 'n deernisvolle houding teenoor hierdie ander, sonder grense of beperking. Juis dít doen Christus, sodat mense vir altyd, oral en in alle omstandighede die "naby"-wees van God as God se seën (Sühnung/versoening) kan ervaar (kyk Cole [1965] 1984:99-100).

God se genade en liefde is dus groter as selfs die ongehoorsaamheid van mense. Sou mense egter steeds die genade van God verwerp, kan hulle nie anders as om God as regter te verwag nie. Volgens 2 Korintiërs 5:10 bly daar steeds 'n dag van rekenskap oor, wat moontlik mag aandui dat Paulus dalk nog van so 'n toekomstige oordeelsdag oortuig was (kyk Tasker [1963] 1983:82-83). Dit is iets wat Johannes nie meer geglo het nie (kyk Joh 5:24; 1 Joh 5:13). God se verhouding met die wêreld, God se liggaam, behoort verstaan te word in die lig van God se vryspraak. "God het die wêreld so liefgehad dat Hy sy [God God se] eie Seun gegee het, sodat dié wat in Hom [Jesus] glo, nie verlore sal gaan nie, maar die ewige lewe sal hê. God het nie sy [God se] Seun na die wêreld toe gestuur om die wêreld te veroordeel nie, maar sodat die wêreld deur Hom [Jesus] gered kan word" (Joh 3:16-17).

Die regter- en koningmetafoor is onlosmaaklik aan mekaar verbind. Die voorbeeld van God, as die Almagtige in Opbenbaring 1:8, is hiervan 'n sprekende voorbeeld. Johannes dui God hiermee as die hoogste gesag aan. Die Almagtige is die Andersmagtige wat begin en wat eindig. Die Almagtige is anders en altyd teenwoordig oor die hele verloop van tyd heen (kyk Morris [1969] 1987:51; vgl Groenewald 1986:38). God wat in die verlede was en vanuit die toekoms na mense toe oppad is, is almagtig in die NÓU van mense se nood teenwoordig. God wat as koning en regter regeer, regeer ook oor dood en graf, oor hooploosheid en oor elke verliessituasie (vgl Rom 6:8-11; 1 Kor 15:54-57; 2 Tim 1:10). Hierdie regverdigheid van God beteken nie 'n verdere las om mense om alles wat gebeur as die oordeel van God te sien nie. Dit beteken eerder dat God wat regverdig oordeel, troos aan mense wil bied wanneer die nood hoog loop.

Wanneer Pilatus Jesus se koningskap uitdaag, antwoord hy: "Ek is 'n koning. Ek moet oor die waarheid getuienis aflê" (Joh 18:37b). Volgens Johannes is Jesus se koninkryk nie van hierdie wêreld nie. Dit is veel groter is as die ryk van die keiser wat deur Pilatus verteenwoordig word (kyk Tasker [1960] 1983:202-203). Dit word bevestig wanneer Jesus, volgens Johannes, vir Pilatus sê: "[U] sou geen gesag oor My gehad het as dit nie van Bo aan u gegee was nie" (Joh 19:11a). 
Die mag wat die Bybel aan God as koning verleen, is groter as die mag van mense. As koning het God die mag om die bande van die dood te verbreek, sodat mense hoopvol kan lewe midde-in verlies. Volgens Matteus 28:18b sê Jesus self: "Aan My is alle mag gegee in die hemel en op die aarde". Die versekering van God se koningskap en heerskappy bied aan mense die hoop om selfs midde-in verlies hoopvol te lewe en vas te hou aan die bevrydende sorg van God wat hooploses laat leef in die verwagtiging dat die koninkryk van die andersmagtige koning ook vir hulle bedoel is.

Die belewenis wat mense van God mag hê, sou binne die raamwerk van die monargiese metafoor te doen hê met afstand. Die heiligheid van God as monarg verdien respek terselfdertyd ook 'n gewillige onderwerping aan die gesag van die koning. Mense wat die reëls van hierdie koninkryk nakom, lewe nie in vrees nie, maar word bevry om hoopvol voor die Koning te lewe (Rom 13:3b-4; kyk Käsemann 1980:350-351). Hierdie metafoor wek ontsag maar bied ook lewensruimte aan die "onderdaan" van God-as-koning om hoopvol te lewe.

Mense wat reeds ly as gevolg van die pyn van verlies behoort nie ook nog die ervaring te hê dat hulle in die beskuldigingsbank staan en hulle vonnis (straf) afwag nie. Die doel is om te troos, nie te beskuldig nie. Die monargies-juridiese metafoor bied ruimte dat God, die Koning en Regter, deur die mede-ly-e van Jesus Christus se teenwoordigheid oor die stukkendheid van lyding en verlies kan triomfeer en regeer. Hiervolgens kan gelowiges met die oortuiging lewe dat God deur Jesus Christus uit liefde en met deernis in beheer en teenwoordig by mense is. Elkeen wat saam met Jesus Christus na singewing midde-in lyding soek, kan deur die teenwoordigheid van Jesus Christus ervaar dat hy of sy nie aan die noodlot uitgelewer is nie, maar met hoop kan lewe van 'n oorwinning oor die nood.

\section{FAMILIEBEELDE}

Familiebeelde is dikwels in die Bybel gebruik om die gesag van God te beklemtoon. Die beelde het egter vandag dikwels nie meer dieselfde seggingskrag as in die Bybelse kulture nie. Daarom merk Hamerton-Kelly (1979:1) op: "[T]he biblical idea of God is suffering a widespread loss of credibility". Die rede vir hierdie gesagsverlies het te doen met die tradisionele gebruik van die beeld van God as "vader". Dreyer (1998:559) stel dit soos volg: 
Wanneer "vader" ... in die Ou Testament gebruik word, is dit deel van 'n versameling beelde geneem uit die familielewe, byvoorbeeld God as bruidegom in die steek gelaat deur sy bruid (Jer 2:1vv), as man wie se vrou hom verlaat het (Hos 2:14vv) en as 'n vader wie se kinders dislojaal was (Deut 32:6; Jer 3:19). In die Nuwe Testament word sulke versamelings van die familiebeeld nie meer gebruik nie. God is "ons Vader" of "my Vader" in Jesus se taalgebruik.

Die teoloog-filosoof Paul Ricoeur meen dat die vaderfiguur nie as 'n statiese konsep verstaan behoort te word nie, maar eerder as 'n raaiselagtige en vloeibare simbool. Hy meen die gebruik van die vaderfiguur as simbool, is " ... a process rather than a structure ... a designation that is susceptible to traversing a diversity of semantic levels, from the phantasm of the father as castrater, who must be killed, to the symbol of the father who dies of compassion" (Ricoeur 1974:468-469).

Die betekenis van ' $n$ beeld kan verander wanneer die konteks verander. Die werklikheid vandag is een van gebroke, enkelouer- en hersaamgestelde gesinne waar die vaderfiguur afwesig is. Die Bybelse patriarg is in so 'n konteks onbekend. Vaderbeelde kan kontra-produktief wees vir menige pastorant en kan in sekere gevalle selfs hulle hoop vernietig. Hamerton-Kelly (1979:5) meen dat die opstand van die jeug teenoor gesagstrukture in die laat sestiger- en vroeë sewentiger jare veel te doen het met die afwesigheid van die vaderfiguur. Die afwesigheid van die vader het "vader" as simbool al hoe meer in diskrediet gebring. Volgens die filosoof Friedrich Nietzsche (in Tellenbach 1976; vgl Hammerton-Kelly 1979:5) is God soos 'n ouerwordende pa wat uiteindelik sal sterf, omdat mense nie daarin kon slaag om God vas te vang in menslike voorstellings nie. Wanneer Jesus volgens die evangelis Lukas in die gelykenis van die verlore seun (Luk 15:11-32) wys op die onkonvensionele optrede van die vader, kry die beeld van die vader nuwe betekenis. Die seun wat "dood" was, word weer deur die vader lewend verklaar.

Daar is sekerlik mense wat vandag " ... 'n patriargale familieverhouding steeds beleef as ' $n$ instelling wat die potensiaal tot geweld en geweldadigheid het" (Dreyer 1998:559). Die vaderbeeld is, soos alle ander beelde, een met beperkings. Die gevaar is dat, wanneer die metaforiese element van hierdie beeld verlore gaan, die beeld te letterlik opgeneem word. Die afwesigheid van die vader in die hededaagse samelewing dra by tot 'n negatiewe konnotasie met die 
beeld van God as vader. Dit neem egter nie weg dat vaderfigure wel ook goed funksioneer en as 'n positiewe beeld kan dien nie.

Hallewas (1989:124) verwys na God as kastydende Vader. Volgens hierdie metafoor behoort lyding 'n opvoedende funksie te hê. Soos 'n pa sy kind sal straf wanneer hy of sy ongehoorsaam was, behoort mense wanneer hulle ly te sê: "Ek glo God is met my besig; God het 'n doel met my lewe". Wanneer mense God beleef as iemand wat hulle laat boet vir hulle dade, deur hulle te laat ly, mag hulle tot die oortuiging kom dat God besig is om van hulle beter mense te maak. Die beeld van God as kastydende Vader lewer egter probleme op, aangesien God nie goed kan wees en terselfdertyd nog straf ook nie. Hierdie "metafoor" hou nie rekening met die mee-lydende-van-straf-gestroopte genade van Jesus Christus, soos wat die Bybel oor die Jesus-gebeure getuig nie.

Hallewas gebruik ook die beeld van God as 'n wonderlike Vader. Dit beteken dat God die dinge wat met mense gebeur, toelaat om te gebeur en dit tot hulle beswil laat dien. In die Brief van Jakobus word gesê dat mense bly behoort te wees wanneer allerlei beproewinge oor hulle kom (Jak 1:2). Dit kom daarop neer dat mense nie vrae mag vra oor die nood in hulle lewens nie, omdat die wonderlike God wil hê dat hulle voordeel sal put uit alles wat met hulle gebeur. Ook hierdie metafoor bied probleme. Dit ignoreer die pyn van mense. As God hierdie "wonderlike Vader" is, is dit 'n vraag waar na die bron en rede van die lyding in die wêreld gesoek moet word. Ek meen dat Jakobus nie die sosioekonomiese omstandighede en lyding wat sy lesers moes verduur, ligtelik verbygegaan het nie.

God as voorsienende Vader word in die Heidelbergse Kategismus (Sondag 10: vraag \& antwoord 27 \&28) aangetref, naamlik dat " ... alles ons nie per toeval nie, maar uit sy Vaderhand toekom", sodat ons " ... in alle teëspoed geduldig en in voorspoed dankbaar kan wees” (Diensboek 1997:142). Dit beteken dat God die geordende bestuurder van alle dinge is en dat niks toevallig met mense gebeur nie. God wil die goeie vir mense bewerkstellig. As mense egter midde-in lyding ervaar dat die goedheid van God ontbreek, vra dit na my mening nie om noodwendig om " ... in alle teëspoed geduldig ... " te wees nie. Dit blyk selfs dat Jesus, volgens sommige van die evangeliste nie sonder meer dit as gegewene wou aanvaar nie (Matt 27:46; Mark 15:34).

In die vroeë sewentigerjare wou verskeie vroueteoloë hê dat die spreektaal in die teologie en liturgie wat hoofsaaklik na God as Vader verwys, hervorm behoort te word. Daly (1973:149) meen dat God totaal her-beeld ("revision") 
behoort te word. Alles wat sleg en gebroke is, kan egter nie aan die manlike figuur alleen toegeskryf kan word nie. Die moederbeeld (vrou-beeld) is ewe beperkend. Daly erken self dat vroue ook nie noodwendig altyd die draers is van wat goed is nie (vgl Daly 1973:95-96). Die betekenis van Daly se werk is die bewuswording dat daar by die allesoorheersende vadersimbool verbybeweeg behoort te word en nuwe simbole ontgin behoort te word. Jesus het self afgewyk van die voorgeskrewe gedragskodes deur aan vroue dieselfde regte toe te ken as wat mans geniet het (kyk Hamerton-Kelly 1979:55). Dit word duidelik waar vroue vir Jesus gevolg het (Mark 15:40-41), waar Jesus met vroue in die openbaar gepraat het (Joh 4:27), en waar Jesus vroue onderrig het (Luk 10:39). Die mees ekstreme voorbeeld is sekerlik waar Jesus toegelaat het dat ' $n$ prostituut die taak van 'n vrou teenoor haar man uitvoer, deur sy voete te was (Luk 7:36-38). Vroue was ook die eerste getuies van Jesus Christus se opstanding (Mark 15:47-16:8). Teen alle gewoontes en gebruike in was Jesus met vroue bevriend en het met hulle gepraat oor wat werklik saak maak in die lewe (kyk Luk 10:38-42; vgl Hamerton-Kelly 1979:60-61). Dreyer (1999:93) wys daarop dat vroue in patriargale samelewings alleen aanvaar is as hulle aan tradisionele ondergeskikte posisies en rolle gekonformeer het. Jesus prys egter Maria, die vrou wat nie konformeer nie, maar aan Jesus se voete sit om saam met die mans geleer te word. Jesus Christus maak mans en vrouens telkens gelyk, wanneer Jesus alle sondes onvoorwaardelik uitwis. Dreyer (1999:94) merk op: "Uit sy [Jesus se] woorde blyk dat hy die sonde van egbreuk ('n oortreding teen die eer van 'n man) gelyk stel met die sondes wat in die harte en lewens van die oordelende persone leef: Laat die een wat 'n skoongewete het, eerste 'n klip op haar gooi (Joh 8:7b)". Ek stem met Jacobs-Malina (1993:116) saam, wat meen dat Jesus Christus se afwyking van die gedragskodes wat voorgeskryf was, die genesing en herstel van mense gesoek het.

God se seën as 'n hoopvolle gebeure midde-in verlies, word versterk wanneer die lydende ook die warmte van die geloofsfamilie ervaar. HamertonKelly (1979:27) stel dat: "[T]o share in God's blessing one had to belong to a family. Thus the status of the father was divinely sanctioned and the divine was involved in the history of the individual and society at the most intimate level, the level of the family". Die patriargale teologie het in die Ou Testament vanuit die familie-konteks ontwikkel. Die seën van die pa aan sy oudste seun was van groot belang vir die voortgang van die redding en verbond wat God aan die familie gebied het. Vanuit hierdie uitgangspunt het oud-Israel Yahweh, die God van die 
vadere, simbolies herformuleer as God, die Vader (kyk Hamerton-Kelly 1979:32). Om kind van God die Vader te kon wees, moes die manlike oud-Israeliet afstand doen van sy eie familie en deur God aangeneem word. Die beginsel van aanneming het hulle dus toegelaat om in te kom en deel van God se familie te wees. Vanuit die perspektiewe van Numeri 11:11-12 blyk dat Israel God nie alleen met manlike metafore ver-beeld het nie. God word ook beskryf as hulle ma wat swanger geword het en hulle in die wêreld gebring het. Die redaktor van Numeri ken simbolies ook die funksie van 'n ma aan God toe.

Jesus Christus het ook deur metaforiese taal die boodskap gebring dat mense bevry en bemagtig word wanneer hulle radikaal met hulle eie familie breek en by God se familie ingesluit word. God se sorg sluit in en nooit uit nie; dit beteken gelyke, hoopvolle waarde en waardigheid aan elkeen. Hamerton-Kelly (1979:61) meen dat dit geensins vreemd is dat hierdie ingesteldheid en optrede van Jesus uiteindelik op die kruis uitgeloop het nie, aangesien dit strydig was met die sosiale reëls van die dag. "Jesus neutralizes the absolute power of the earthly father by means of claims of the heavenly father" (Hamerton-Kelly 1979:102).

As Ouer, Vader en Moeder staan God se sorg met hierdie metafoor op die voorgrond. God se sorg is nie los te dink van 'n familie- of gesinstruktuur nie: "Ek sal vir jou 'n God wees en ook die God van jou nageslag" (Gen 17:7). Dit herinner mense aan die sorg, beskerming, opvoeding en onderrig wat 'n ouer aan 'n kind gee. Wanneer die pastor saam met die pastorant die rouproses aan die hand van die familiemetafoor wil verryk, behoort die ongelykheid tussen man en vrou in die eerste eeuse Meditereense wêreld in ag geneem te word (kyk Dreyer 1999:79). Mans was bó vroue geag, soos wat God bó mense geag is. Jacobs-Malina (1993:75) meen dat daar tussen die meerwaardigheid van die man en die minderwaardigheid van die vrou 'n onoorbrugbare kloof in 'n patriargale kultuur, soos dié in die leefwêreld van die Bybel, bestaan het.

In reaksie hierop bied Miller (1989:149) die resultate aan van Samuel Osherson, van Harvard Universiteit wat navorsing op gesinstrukture in Noord Amerika gedoen het. Osherson stel dat:

... the psychological or physical absence of fathers from their families is one of the great underestimated tragedies of our time ... [N]inety per cent or more of children of divorced parents stay with their mothers, whose pre-eminent stake in children has been enhanced by feminist demands and by a consequent easy rationalization of male irresponsibility ... [T] he return to motherhood as a feminist ideal is only 
possible because feminism has triumphed over the family as it was once known, and women's freedom will not be limited by it.

Alhoewel hierdie woorde radikaal mag klink, kan dit eenvoudig nie geïgnoreer word dat die samestelling, sowel as die hersamestelling van gesinne noodwendig daartoe lei dat die tradisionele wyse waarop mense God ver-beeld het, nuut bedink behoort te word nie. Ek is van mening dat, indien daar vasgehou word aan enkele beelde ten koste van ander, dit nie die rouproses sou verryk nie. Die Spreukedigter wil in Spreuke 4:3-4 iets van die balans wat daar behoort te wees, uitspel: "Ek was ook eenkeer 'n kind, my moeder se oogappel, haar enigste. My vader het my toe ook geleer ...".

God is altyd manlik én altyd vroulik en tog ook nóg manlik, nóg vroulik. God is meer as die somtotaal van eienskappe wat metafories aan God toegeken kan word. God is God, die On-sê-bare, wat deur mense metafories sê-baar gemaak word in en deur die weldade van die opgestane Jesus Christus. God, wat grens en tyd oorsteek deur immanent by mense teenwoordig te wees, kan eweneens nie binne die grense van geslagtelikheid vasgevang word nie. Om die sorg van God tydens die rouproses te verstaan, is dit nodig dat manlike en vroulike metafore gebruik sal word. Hiermee word nie gepoog om enige geslagtelikheid aan God te koppel nie. Dit sê: God is volledig in God se omvattende sorg by mense teenwoordig is.

McFague (1988:98) stel dat " $\ldots$ there is no gender-neutral language if we take ourselves as the model for talk about God, because we are sexual beings". Om na God as vader of moeder te verwys, het noodwendig geslagtelike konnotasies, maar wil terselfdertyd iets sê van die onderskeidelike wyses waarop 'n pa en 'n ma sorg. Indien God as 'n vader ver-beeld sou word, sonder om ook die "vroulikheid" van God te ver-beeld, sou die gebruik van Godsbeelde op 'n bepaalde metaforiese afgodsdiens neerkom, omdat God uitstyg bo tyd, ruimte en geslagtelikheid. Wanneer daar aan God as vader of moeder gedink word, verwys die metafore tergelykertyd na God wat met deernis sorg, omgee, beskerm, sekuriteit verskaf, skeppend voortbring, voed en opvoed. God as Vader-MoederGod, verteenwoordig lewe en geborgenheid.

Om die familie-metafoor uit te brei van God as vader na God as moeder en as ouer, het verreikende implikasies vir die rouproses, omdat mense midde-in verlies daardeur bemagtig kan word sodat hulle tevredenheid kan vind "[S]oos 'n kindjie wat by sy moeder tevredenheid gevind het" (Ps 131:2). Die moeder- 
metafoor kan in die huidige samelewingskonteks, soos aangehaal in die werk van Miller (1989:149) van betekenis wees. Waar kinders, weens die verlies aan 'n gesonde huwelik, blootgestel word aan 'n egskeiding, en by óf die pa óf ma sou wees, kan hierdie metaforiese elemente met groot vrug vir die kinders ingespan word.

Ek oordeel dat die post-moderne konteks hierdie familie-metafoor noodsaak. Die tradisionele beeld van God as vader hoef nie in diskrediet gebring te word nie. Dit kan egter in die huidige konteks op 'n meer sinvolle en vollediger wyse gestalte kry.

\section{VRIENDSKAPSBEELDE}

Midde-in lyding en verlies beleef mense dikwels 'n gevoel van God se afwesigheid. Waarom-vrae word gestel. Waar was God toe die natuurramp verwoesting gesaai het? Van Wyk (1988:451) bring hierdie vrae in perspektief wanneer hy vra: "Is God glad nie by lydendes teenwoordig nie of gryp God nie in om die wense van die lydende te verwesenlik nie? Is die probleem dus die wese van God of die handelinge van God? ... Of handel dit oor 'n onvolledige Godsverstaan? Kan God of is God ooit werklik afwesig?". 'n Mens sou kon vra of die "afwesigheid" van God nie dalk beteken dat God nie die wense van mense op 'n gegewe tydstip verwesenlik het nie. Dit sou beteken dat die wil/handelinge van mense en die wil/handelinge van God deurmekaar geloop het en dat mense die fout maak om die afwesigheid van bepaalde emosies, soos byvoorbeeld vrede, toe te skryf aan die afwesigheid van God.

Heyward (1982:7) meen dat die kragtige teenwoordigheid van God gesoek behoort te word in die relasionele krag van God, eerder as in patriargale krag van mag en geweld. Alhoewel daar baie van God se relasionele krag opgesluit lê in God se vriendskapsverhouding met mense, kan die pastor en pastorant nie uit die oog verloor dat vriendskap verskillende betekenisse in verskillende tye gehad het en ook in die toekoms sal hê nie. Volgens Keener (2000:380) kom die begrip "vriendskap" nie eksplisiet in die die Nuwe Testament voor nie. Die evangelis Johannes (15:15) verwys egter wel na Jesus as vriend van mense. Vriendskap in die tyd van die Nuwe Testament is gesien as 'n persoonlike verhouding tussen twee. "Friendships could be either a relationship of equality or dependence, personal or impersonal" (Dreyer 2002:53). Dit is anders as vriendskap wat vandag as ' $n$ wederkerige verhouding tussen gelykes verstaan word. 
As vriend, bondgenoot en vertroueling kry Jesus se woorde in Johannes 15:13-15 besondere betekenis vir die rousmartsituasie. Die teenwoordigheid van God kan ervaar word as bondgenootskap. Die "verhewe status van vriende van Jesus" (Groenewald 1980:327) hang daarvan af of mense die opdragte van Jesus Christus uitvoer. Dit gaan hier dus om 'n verhouding wat tussen Jesus Christus en mense bestaan. Mense is vertrouelinge en rentmeesters van God. Hiervolgens merk Dreyer 2002:54 op: "Though the ideal of equality was strong and it was indeed a great honor to the person regarded by the friend as an equal, friendships in antiquity were not just free voluntary relationships". Volgens Meeks (1983:30) was 'n vriendskapsverhouding in antieke tye gekenmerk deur "obligations and expectations". Dit bevestig Jesus se uitspraak teenoor die dissipels: "Niemand het groter liefde as dit nie: dat hy sy lewe vir sy vriende aflê. Julle is my vriende as julle doen wat Ek julle beveel" (Joh 15:13-14a).

Die lydensweg wat Jesus Christus moes stap, ver-beeld God as die afwesige-aanwesige God en is 'n teken van God se vriendskapsliefde vir sondaarmense. God staan nie apaties teenoor mense en hulle lyding nie. God is vriendelik, liefdevol, handelend en bevrydend in die Jesus-gebeure teenwoordig wanneer mense op grond van hulle lyding in 'n cul de sac beland het en nie magteloos afwesig in die lyding en verlies van mense nie. Die Vriend is uit liefde, handelend teenwoordig. Wanneer Müller-Fahrenholz (2000:1022-1023) aan die woorde van Jesus met die instelling van die Nagmaal dink, beklemtoon sy opmerking iets van God wat vriendelik teenwoordig by mense is: "There is an element of violent transformation that we need to keep in mind as we receive bread and wine. Because of this transformation they are sacramental signs of what Christ went through, who let himself be killed so that we may live. The love of God appears as the radical being for others". Wanneer die evangelieskrywers opmerk dat Jesus sou verkondig dat die koninkryk van God naby gekom het, is die bedoeling juis om God se nabyheid sonder tussengangers soos die priesters of kultus te beklemtoon. Van Wyk (1988:453) meen dat, waar mense God beskuldig van 'n apatiese, magtelose afwesigheid, dit 'n kenmerk is van “ ... 'n verskraalde Godsbegrip".

Vriendskap met God in lyding, dui op God se teenwoordigheid in tye van nood. Vriendskap met God verryk mense in hulle soeke na hoop. Vriendskap met God dui op hierdie "element of violent transformation" soos wat die Bybel die Jesus-gebeure aan mense vertel. Hierdie metafoor is anders as die familiemetafoor. Spreekwoordelik is dit waar dat ' $n$ vriend in nood, beter is as ' $n$ broer in 
die verte. Die gerigtheid van vriende op mekaar dui op 'n besondere verhouding van bondgenootskap, vertroue, empatie, affiliasie en toegewendheid teenoor mekaar. Dreyer (2002:53) sluit hierby aan as sy opmerk dat: “ ... mutuality in a symmetrical relationship would probably be regarded as a necessary requirement for friendship. So also will friendship be regarded as a personal relationship". Wanneer Jesus volgens Johannes 15:13 sê: "Niemand het groter liefde as dit nie: dat hy sy lewe vir sy vriende aflê", dui dit op 'n openheid en onbaatsugtige, onselfsugtige opofferende vriendskapsverhouding. Daar behoort in gedagte gehou te word dat daar 'n verskil in gelykheid in antieke vriendskapsverhoudings en vriendskapsverhoudings van vandag is (kyk Dreyer 2002:53)

'n Vriendskapsverhouding het die betekenis dat daar vir mense in nood 'n skouer is om op te leun. Jesus Christus se vriendskap in nood, naamlik dat Hy bereid was om sy lewe af te lê, beteken dat God se dáár-wees, God se presentwees, toegesê word aan mense. Hoewel hierdie metafoor in en deur die Jesusgebeure nuwe en besondere betekenis gekry het, het dit ook relevansie vir vandag. Hierdie metafoor dui op God se andersoortige en unieke teenwoordigheid by mense in lyding. Deur God se genade sê God Godself onvoorwaardelik toe aan mense, ondanks sonde en gebrokenheid. Deur die kruis en opstanding van Jesus Christus, gee God ware vriendskap aan mense. Louw (1997b:19) sê: "Hy is 'n Vriend, dwarsdeur die dood". So stel McFague (1988:159) ook dat: " ... friendship exists in freedom and as such is the rarest and most priceless treasure ... friends choose together". McFague meen dat die vriendskapsmetafoor een van die mees bevrydende metafore is, omdat dit die liefde van God vir en teenoor die wêreld uitdruk. Hierdie metafoor kan vir mense midde-in lyding 'n veilige hawe van geborgenheid en veiligheid skep, waar mense met verlies steeds hulleself kan wees ten spyte van verlies.

Die vriendskapsmetafoor impliseer verbond, ver-bond-enheid, ver-bindtenis, ver-bind-ing, binding - 'n binding van vertroue en verbintenis. Hierdie metafoor is tydloos. Dit strek oor die grense van geslag, klas, nasionaliteit, ras, ouderdom en geloof. McFague (1988:164) stel: "We can be friends with other forms of life in our world - we can be friends with God". Die vriend-metafoor is 'n hoop-metafoor; dit is ' $n$ God-met-ons-metafoor. Dit is 'n metafoor wat vertel dat God teenwoordig is as vriend en mede-lyer midde-in die lyding van mense. 


\section{BEELD VAN GOD AS GELIEFDE}

Waar Johannes in sy briewe sê: "God is liefde", het dit die betekenis dat die liefdes-metafoor " ... should be totally giving, with no thought of finding value in the loved object and no need of response from the one loved" (McFague 1988:125). Hierdie argument bou McFague later uit deur te stel dat God vir haar persoonlik is, maar nie 'n persoon nie. God se liefde beteken dat God persoonlik is, maar daarnaas word die persoonlike metafoor ook terug gevind in elemente soos Gees, lewe, lig, water, waarheid en andere, wat aspekte van die skepping van God insluit. God kan nie minder as persoonlike God wees nie (McFague 2001:18).

Die verhouding van Jesus Christus en die kerk word uitgedruk in terme van 'n Bruidegom-bruid verhouding (Ef 5:21-32). Efesiërs 5:25-26 getuig van Jesus Christus, as die Geliefde, die Minnaar, die Bruidegom van die kerk, wat besig is om die kerk (die geloofsgemeenskap) voor te berei om heilig en onberispelik voor Jesus self te staan. Hierdie Skrifgedeelte vervul 'n paranetiese funksie. Dit dui aan dat gelowiges die noodsaaklikheid behoort te verstaan om 'n moreel-eties skoon lewe te lei as gemeente wat aan Jesus Christus getrou moet wees. Om van hierdie metafoor gebruik te maak, sal dit van belang wees om te verstaan dat die geloofsgemeenskap die voorwerp van God se liefde en trou en selfoorgawe is. Elkeen wat dus verlies ervaar en deel van die geloofgemeenskap is, kan met dieselfde hoop op ' $n$ sin-volle lewe ten spyte van verlies leef.

Wanneer die pastor hierdie beeld van God, wat in Jesus Christus die Geliefde van die geloofsgemeenskap is, in die rouproses van toepassing wil maak, behoort die betekenis van die metafoor binne 'n eie konteks verstaan te word. Liefde in die antieke huwelike, was nie wat vandag as liefde in die huwelik verstaan word nie. Hieroor meen Dreyer (1999:93): "[D]ie huwelik is by uitstek die plek waar die vrou as randfiguur en minder-bevoorregte funksioneer. Sy word soos 'n soort besitting aangeskaf en behandel. As werker in diens van haar man se familie moet sy onverpoosd arbei en kinders baar. Sy verkry geen posisie in die nuwe familie nie en word nooit beskou as bloedfamilie nie". Wanneer Jesus Christus egter egskeiding verbied, word man en vrou in en deur Jesus gelyk gemaak. Vroue se regte word in die huwelik deur Jesus Christus herstel, sodat hulle nie meer, soos in die geval van 'n patriargale verhouding, deur hulle mans "weggestuur" kan word nie. Jesus Christus neem die reg wat die man gehad het om van sy vrou te skei, weg. Wanneer mans en vrouens se huwelike deur die Jesus-gebeure beïnvloed is, word hulle "een vlees" en dus bloedfamilie van 
mekaar (kyk Dreyer 1999:93). Waar Jesus Christus as Bruidegom en Geliefde van die geloofsgemeenskap op só 'n wyse binne huidige terme nuut ver-beeld word, kan gelowiges midde-in verlies die ervaring hê dat hulle 'n Geliefde het, met wie hulle bloedfamilie geword het. Die Jesus-gebeure vertel 'n verhaal van God wat as Geliefde by mense teenwoordig is, wanneer die konteks getuig dat mense as gevolg van hulle verlies, gemarginaliseer word. Deur God se hoopvolle teenwoordigheid, waarvan die Bybel in die Jesus-gebeure getuig, het God medelye met elkeen wat ly. John McDargh (1986:262) merk op: "The God who proclaimed, 'Behold I make all things new' can be witnessed constantly correcting, enlarging, and re-forming the imagings of our heart that are the necessary but always inadequate efforts we are humanly compelled to make to answer the question, 'Who is there for me?'”

Die geestelike eenwording met Jesus Christus, lê opgesluit in die werking van die Gees wat as Trooster met mense in lyding identifiseer. Hierdie metafoor word ver-beeld in die verhaal van Hosea, waar God steeds die getroue minnaar bly, selfs al is die bruid ontrou. In lyding en verlies skep die liefde-metafoor die moment van hoop, liefde, vreugde en vrede.

McFague (1988:130) stel dit soos volg:

We speak of God as love but are afraid to call God lover. But a God who relates to all that is, not distantly and bloodlessly, but intimately and passionately, is appropriately called lover. God as lover is the one who loves the world not with the fingertips but totally and passionately, taking pleasure in its variety and richness, finding it attractive and valuable, delighting in its fulfillment. God as lover is the moving power of love in the universe, the desire for unity with all the beloved, the passionate embrace that spins the "living pulsing earth" around, send the "blood through our veins", and "draws us into one another's arms".

Hoewel McFague in die Calvinistiese tradisie staan, is haar motief van God as Geliefde ingebed in die Rooms-Katolieke selibaatbeginsel (kyk Bynum, in Moore \& Reynolds 1984:104-125).

\section{GODSBEELDE: 'N KEUSE}

Wanneer pastorante God metafories ver-beeld, bestaan die moontlikheid om te verval in die gebruik van net een stereotipe Godsbeeld en gevolglike uitleg 
daarvan. So sou lyding byvoorbeeld toegeskryf kon word aan God wat oordeel en straf vir wat mense verkeerd doen.

Indien kontekste verskil, sal die betekenis van die metafoor verskil, al word dieselfde metafoor gebruik. Die gebruik van metafore behoort inklusief te wees, sodat een nie bo 'n ander verhef word nie. Die ver-beelding van God word gedoen met die oog op soeke na sin sodat die hoop in Jesus Christus midde-in verlies kan deurbreek. Die gebruik van metafoorgroeperings hou voordele in. Die gebruik van enkelvoudige metafore sal nie die heil in Jesus Christus omvattend kan beskryf nie. Persone wat ly soek nie net na die betekenis van God as vader of moeder of regter nie, maar na die totaliteit van God se medelye met mense. Voorkeur aan spesifieke Godsbeelde vir spesifieke pastorale omstandighede, sou die moontlikhede tot hulp vir die pastorant verskraal. Die volle rykdom van moontlikhede om God te beskryf en te ervaar, is tot die lydende persoon se beskikking.

David Tracy (1995:32) stel dat: "God, and God alone, as the Wholly Other One, is both transendent to all reality and totally immanent in all reality". In die ver-beeld-ing van God, kan God se afstand, waar God as regter en koning regeer, nie losgemaak word van God se nabyheid as vriend nie. Vir gelowiges word Jesus Christus in die Nuwe Testament naby-God, Immanuel. God se afstand van en regering oor die wêreld, is ook God se teenwoordige liefde vir en ondersteuning van die wêreld. McFague (2001:134) omskryf die liefde van God as “... God's transendence at the expense of immanence". Hiervan getuig Paulus in Filippense 2:8: "Hy wat in die gestalte van God was, het sy bestaan op Godgelyke wyse nie beskou as iets waaraan Hy Hom moes vasklem nie, maar Hy het Homself verneder deur die gestalte van 'n slaaf aan te neem en aan mense gelyk te word". God word mens ter wille van mense. God wil in alles en ten koste van alles, soos verbeeld in die Jesus-gebeure, mede-lydend by die wêreld teenwoordig wil wees. Die gebruik van metafore kan nie gereduseer word nie. Jesus Christus herïnterpreteer metafore wanneer Jesus sê dat die koninkryk van God naby gekom het. God se radikale anders teenwoordigheid by mense beteken dat: "[l]n plaas van 'n koning praat hy [Jesus] van 'n vader wat nie manipulerend uitbuit nie, maar sorg dra deur vir almal in die huishouding hulle 'daaglikse brood' te gee ... Hier is daar nie sprake van eksklusiwiteit nie - nie ten opsigte van buitestaanders nie, nie ten opsigte van kinders nie, en ook nie ten opsigte van geslag nie" (Dreyer 1999a:90). Op grond van die teenwoordigheid van God in Jesus Christus, in die hooplose wêreld van mense, word mense in 
staat gestel om te kan sê: "Want so lief het God die wêreld gehad ... " (Joh 3:16). God se liefde is liefde vir die wêreld, liefde wat tot uitdrukking kom wanneer God as vader, moeder, vriend, regter, koning, skepper en ook in terme van enige ander metafoor waarmee mense God in hulle gebroke wêreld mee verbeeld (kyk Mc Fague 2001:17), by mense teenwoordig is.

Ek meen dat die liefde van God wat tot uiting kom in die hoopvolle menswording van Jesus Christus, die moontlikheid oop laat dat daar steeds ander metafore bygevoeg kan word, selfs metafore wat nie in Bybelse konteks genoem word nie. Die Bybel het nie klaar oor God gepraat nie, omdat God nog nie klaar gepraat het in die lewe van mense nie. God bly steeds handelend teenwoordig in God se wêreld. Die liefde van God, wat begrond word in die hoopvolle teenwoordigheid van Jesus Christus, laat 'n bevrydende oop einde aan 'n metaforiesver-beeld-ende spreke aangaande God. Mense beskuldig God van 'n apatiese, magtelose afwesigheid. Dit is kenmerk van " ... 'n verskraalde Godsbegrip” (Van Wyk 1988:453). In 'n situasie van rousmart kan Godsbeelde bydra tot 'n beter en verrykende ervaring van God, die self, ander (kyk Louw 1997:387). Louw (1997:13) stel dat so 'n model “ ... 'n teleïtiewe model genoem kan word”, omdat

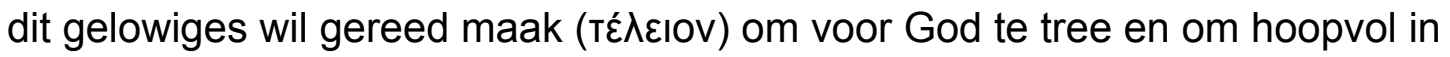
die teenwoordigheid van God te leef (Fil 3:10-11). Indien wel voorkeur aan spesifieke beelde verleen sou word, meen ek dat Jesus, die Vriend van mense, verteenwoordigend sou kon wees van verskeie ander beelde. Dit is 'n beeld waar God, uit liefde, omgee en deernis by mense teenwoordig is en waar mense gereed gemaak word om met hoop, midde-in en ten spyte van verlies, hoopvol voor God te lewe.

\section{Literatuurverwysings}

Cole, R A [1965] 1984. Galatians. Grand Rapids, MI: Eerdmans. (Tyndale New Testament Commmentaries.)

Daly, M 1973. Beyond God the Father: Toward a philosophy of women's liberation. Boston, MN: Beacon.

Diensboek van die Nederduitsch Hervormde Kerk van Afrika 1995. Doornfontein: Perskor.

Dreyer, Y 1998. Pastorale interaksie met vroue: 'n Prakties-teologiese begronding. DDverhandeling, Pretoria: Universiteit van Pretoria.

Dreyer, Y 1999a. Vroue-ervaring en spiritualiteit. HTS 55(2\&3), 360-379.

Dreyer, Y 2002. Women and leadership from a pastoral perspective of friendship. HTS 58(1), 43-61. 
Groenewald, E P 1980. Die Evangelie van Johannes. Goodwood: Nasionale Boekdrukkery.

Hallewas, C F G E 1989. In de schaduw des doods. Hardinxveld: Theologische Uitgeverij Narratio.

Hamerton-Kelly, R 1979. God the Father: Theology and patriarchy in the teaching of Jesus. Philadelphia, PA: Fortress Press.

Jacobs-Malina, D 1993. Beyond patriarchy: The images of family in Jesus. New York, NY: Paulist Press.

Käsemann, E 1980. Commentary on Romans. Grand Rapids, MI: Eerdmans.

Louw, D J 1997b. 'n Diagnostiese model vir die assessering van spiritualiteit met die oog op geloofsontwikkeling in die pastorale bediening. Praktiese Teologie in SuidAfrika. Vol 12(2), 11-25. Pretoria: UNISA.

McFague, S 1987. Models of God: Theology for an ecological, nuclear age. Minneapolis, MN: Fortress.

McFague, S 2001. Life abundant: Rethinking theology and economy for a planet in peril. Minneapolis, MN: Fortress.

Meeks, W A 1983. The first uban Christians: The social world of the apostle Paul. New Haven, CT: Yale University Press.

Müller-Fahrenholz, G 2000a. Healing the wounds of nations: Towards a common missions of the churches. HTS 56(2\&3), 608-622.

Müller-Fahrenholz, G 2000b. Forgiving is a way of healing: Theological approximations. HTS 56(4), 1009-1023.

Ricoeur, P 1974. The conflict of interpretations: Essays in hermeneutics. Evaston: North Western University.

Sarot, M 1994. Ons lijden en Gods medelijden. Nederlands Theologisch Tijdschrift 48(2), 131-140.

Tasker, R V G [1960] 1983. John. Grand Rapids, MI: Eerdmans. (Tyndale New Testament Commmentaries.)

Tasker, R V G [1963] 1983. 2 Corinthians. Grand Rapids, MI: Eerdmans. (Tyndale New Testament Commmentaries.)

Tellenbach, H Hrsg 1976. Das Vaterbild in Mythos und Geschichte. Stuttgart: Kohlhammer.

Tracy, D 1995. The paradox of the many faces of God in monotheism. Maryknoll, NY: Orbis.

Van Wijk-Bos, J W H 1995. Reimagining God: The case for Scriptural diversity. Louisville, KY: John Knox.

Van Wyk, I W C 1988. Die "verleentheid" van die teoloog voor die teodisieeprobleem. HTS 44(2), 450-461. 